Отримано: 8 листопада 2021 p.

Прорецензовано:13 грудня 2021 р.

Прийнято до друку: 13 грудня 2021 р.

e-mail: by-ru@list.ru

DOI: $10.25264 / 2415-7384-2022-14-42-45$
Svilo Ya. V. Features of emotional intelligence of children of divorced parents and its relationship with sociometric status in primary school age. Наукові записки Наиіонального університету «Острозька академія». Серія «Психологія» : науковий журнал. Острог : Вид-во НаУОА, січень 2022. № 14. С. 42-45.

\title{
FEATURES OF EMOTIONAL INTELLIGENCE OF CHILDREN OF DIVORCED PARENTS AND ITS RELATIONSHIP WITH SOCIOMETRIC STATUS IN PRIMARY SCHOOL AGE
}

This article highlights the actuality of the study of emotional intelligence. Emotional intelligence is considered as a factor contributing to the adaptation and socialization of the individual. The concept itself is viewed in a broad sense as the ability to control feelings and emotions, to distinguish between oneself and other people, and also to use this knowledge to control one's thoughts and actions. The article focuses on the fact that emotional intelligence is especially intensively developed exactly at primary school age, while experiencing numerous transformations and changes.

The results of available research in the diagnosis of emotional intelligence by children of primary school age (Ryzhov D.M.) are presented. Within this article, it was carried out the study of the emotional intelligence by children of primary school age and the identification of the features of the emotional intelligence of children of divorced parents. In total, 153 children of primary school age, representatives of both sexes, took part in this study.

Using the technique "Special awareness: emotions and feelings" by E. I. Izotova, the following results were obtained: statistically significant differences were noted on most scales of the questionnaire ("Expression of emotions", "Causes of emotional experiences", "Empathy") and on the overall level of emotional intelligence. Children of divorced parents have a higher level of emotional intelligence than children living with both biological parents.

Moreover, the diagnosis of the sociometric status of children of divorced parents of primary school age was carried out using the "Sociometry" technique (J. Moreno, adapted by Ya. L. Kolominsky). In this group, there is a predominance of children with the sociometric status of "preferred", which in turn is favorable and indicates the inclusion of the individual in society. It was put forward a hypothesis about the connection between the level of emotional intelligence and sociometric status in children of divorced parents of primary school age, but it was not confirmed, there is no statistically significant connection.

Thus, as a result of the study, it was revealed that children of divorced parents have higher indicators on most scales and on the overall level of emotional intelligence than children living with both biological parents. They have a better developed ability to understand their emotions and the emotions of other people, the ability to understand the reasons that caused these emotions, as well as predict the emotions of others and manage their own. Also, the children of divorced parents have a favorable sociometric status. They are accepted in class and have enough social contacts. All this makes it possible to assume that, in general, these children are sufficiently adapted and socialized in society. However, their sociometric status does not depend on the degree of development of their emotional intelligence.

Keywords: emotional intelligence, primary school age, sociometric status, socialization, parents' divorce.

\author{
Свіло Яніна Володимирівна, \\ аспірантка кафедри психологї \\ Гомельського держсавного університету імені Ф. Скорини
}

\section{ОСОБЛИВОСТІ ЕМОЦІЙНОГО ІНТЕЛЕКТУ ДІТЕЙ, РОЗЛУЧЕНИХ ІЗ БАТЬКАМИ, І ЙОГО ВЗАЄМОЗВ'ЯЗОК ІЗ СОЦІОМЕТРИЧНИМ СТАТУСОМ У МОЛОДШОМУ ШКІЛЬНОМУ ВІЦІ}

У статті підкреслено актуальність вивчення емоиійного інтелекту. Емоиійний інтелект розглянуто як чинник, щзо сприяє адаптації та соиіалізації особистості. Саме поняття розтлумачено в широкому сенсі як здатність керувати почуттями й емочіями, розрізняти свойх та інших людей, а також використовувати ці знання для управління своїми думками і діями. Наголошено на тому, щзо емоиійний інтелект особливо інтенсивно формується і розвивається саме в молодиому шкільному віці, відчуваючи численні перетворення $і$ зміни. Наведено результати вже наявних досліджень діагностики емоиійного інтелекту дітей молодшого шкільного віку (Д. М. Рижов). Досліджено емоиійний інтелект дітей молодшого шкільного віку й виокремлено особливості емоиійного інтелекту дітей, розлучених із батьками. В опитуванні взяло участь 153 дитини молодшого шкільного віку обох статей. За допомогою методики «Спеціальна обізнаність: емочії і почуття» Е. І. Ізотової здобуто такі результати: за більшістю шкал опитувальника («вираз емоцій», «причини емоційних пережсивань», «емпатія») $i$ за загальним рівнем емоційного інтелекту засвідчено статистично значущі відмінності. У дітей, розлучених із батьками, рівень емоційного інтелекту вищий, ніж у дітей, які проживають з обома біологічними батьками. Проведено діагностику соиіометрич- 
ного статусу дітей молодшого шкільного віку, розлучених із батьками, за допомогою методики “Соиіометрія» (Дж. Морено, в адаптації Я. Л. Коломінського). У иій групі засвідчено перевагу дітей із сочіометричним статусом «бажаний», який свідчить про залученість особистості в соиіум. Висунуто гіпотезу про взаємозв 'язок рівня емоиійного інтелекту й соиіометричного статусу в дітей молодшого шкільного віку, розлучених із батьками, проте ї̈ не підтверджено: статистично значущзого взаємозв'язку немає.

3'ясовано, щзо в дітей, розлучених із батьками, за більшістю шкал $і$ за загальним рівнем емоційного інтелекту показники вищі, ніж у дітей, які проживають з обома біологічними батьками. У них краще розвинена здатність розуміти свої емоції та емоції інших людей, здатність розуміти причини, цчо викликали цуі емоції, а також прогнозувати емоиії інших і управляти власними. Так само у дітей, розлучених із батьками, переважсає сприятливий сочіометричний статус. Вони прийняті в класі й мають достатньо сочіальних контактів. Усе цее дає можливість припустити, щзо загалом ці діти досить адаптовані й соиіалізовані в суспільстві. Однак їхній соціометричний статус не залежить від ступеня розвитку в них емоційного інтелекту.

Ключові слова: емочүійний інтелект, молодиий шкільний вік, сочіометричний статус, сочіалізація, розлучення батьків.

Introduction. The importance of emotions and the development of emotional intelligence in various fields of human activity is the subject of indisputable interest in scientific research, due to its connection with the development of more adaptive and less pathological behavior [1]. Emotions form the first system of human communication before the development of language.

Theoretical analysis of the problem. D. D. Major and P. Solovey defined emotional intelligence as the ability to manage feelings and emotions, distinguish them and use this knowledge to control one's thoughts and actions. Currently, emotional intelligence is conceptualized as a construct structured by four groups of interrelated and hierarchically established abilities in accordance with the psychological function they perform [2].

Through socialization, people, in interaction with others, learn ways of thinking, feeling and acting that will allow them to participate effectively in the life of society [3;4]. Thus, emotions are also the object of socialization, but they represent something more: they play a fundamental role in own development. From the moment of birth, they connect the child with the social world and humanize him [5].

According to O. N. Istratova, the emotional intelligence is developed especially intensively at primary school age, being unformed in the process of development, it experiences numerous transformations and changes. This is determined by some reasons. The first reason is spiritual changes, when, as a child grows and develops, he changes his view of the world around him; the second reason is the social processes taking place in society, which have a great influence on the development of emotional intelligence [6].

Ryzhov D. M. has found in the course of a diagnostic study aimed at studying the emotional intelligence of primary school children the following facts. The average level of development of emotional intelligence and its components is typical for the majority of younger schoolchildren. Children of this age rarely have a high level of emotional intelligence. Next, we have to work on the development of emotional intelligence of younger schoolchildren and analyze the productivity of such activities [7].

Many modern Russian scientists in the field of psychology study the features of emotional intelligence in primary school age. L.Yu. Komlik and V.S. Merenkova in their work studied emotional intelligence at primary school age and hypothesized the existence of a connection between emotional intelligence and the style of family education, they revealed a significant connection [8]. A. V. Solovyova, studying emotional intelligence at primary school age, also comes to the conclusion about the influence of child-parent relations on it, suggesting for optimization the level of emotional intelligence the usage of methods of interactive communication parents and their children, such as "Book of Life", "Life Map", "Ecocard", "The Tree of Life" [9, c. 144]. The connection of emotional intelligence with factors of family upbringing and child-parent relations revealed by other authors makes it possible to put forward a hypothesis about the influence of parental divorce on the level of emotional intelligence in primary school age. The main factor in the development of emotional intelligence is the child's relationship with the family, since the family is the first social sphere that determines his development, and the basis for the formation of his dominant emotional states. The family is the source of the first positive and negative experiences and emotions of the child. This forms the foundation for the development of emotional intelligence [10]. At the same time, A. A. Osipova notes that school is also an important factor in the development of emotional intelligence. Entering school life, the child begins to interact energetically with classmates, makes new friends, and takes part in the life of the team. A child may have problems in relationships with others due to poor adaptation or excessive shyness. At school, pupils are allowed to evaluate their own actions; it can lead to the emergence of self-control [11]. Based on these data, it can be assumed that the relations in the school team (class) have a direct impact (like the family) on the formation of the level of emotional intelligence. Accordingly, the sociometric status of children may have a connection with the level of emotional intelligence in primary school age, and by increasing one of these factors, we can contribute to the increase of the second.

Research objectives: 1) the study of the features of emotional intelligence of children of divorced parents and children living with both biological parents; 2) the analysis of the statistical significance of differences in 
the level of emotional intelligence children of divorced parents and children living with both biological parents; 3) the study of the sociometric status of children of divorced parents; 4) analysis of the influence of the level of emotional intelligence on the sociometric status of children of divorced parents of primary school age.

Characteristics of the study sample. In total, 153 children of primary school aged 8-9 years participated in the study, 86 children living with both biological parents and 67 children of divorced parents. The sample shows an approximately equal ratio of girls and boys.

Research methods. The methodology "Special awareness: emotions and feelings" by E. I. Izotova and "Sociometry" (J. Moreno, adapted by Y. L. Kolominsky).

The results of the study. The methodology "Special awareness: emotions and feelings" by Izotova E. I. was used to diagnose emotional intelligence in primary school age. The survey was conducted in an individual form, the analysis was carried out on all scales of the questionnaire, the overall level of emotional intelligence was also analyzed.

The following results were obtained in children living with both biological parents. According to the "Content of emotions and feelings" scale, the average score is 4.52 out of 6 maximum points. On the "Expression of emotions" scale, the average value is 8.91 points, with the maximum possible 12 points. On the scale "Causes of emotional experiences", the average is 6.01 with the maximum possible 8 points. On the "Empathy" scale, the average level for the group is 4.26 , with the maximum possible 6 points. Dwelling on the general level of emotional intelligence, an analysis was carried out based on a comparison of the data obtained with the norm indicators (proposed by the author of the test): $61.63 \%$ of children have a normal level of emotional intelligence, $38.37 \%$ of children have a level below the norm.

The following results were obtained in children of divorced parents. According to the "Content of emotions and feelings" scale, the average score is 4.61 points. On the "Expression of emotions" scale, the average value is 9.75 points. On the scale of "Causes of emotional experiences", the average score is 6.67 points. On the "Empathy" scale, the average level for the group is 5.02 points. Dwelling on the general level of emotional intelligence, an analysis was carried out based on a comparison of the data obtained with the indicators of the norm: $82.09 \%$ of children have a normal level of emotional intelligence, $17.91 \%$ of children have a level below normal.

With the help of the Mann-Whitney U-test, it was conducted a statistical analysis of the significance of differences in the level of emotional intelligence in children at primary school age, depending on the experience of parents' divorce in their lives. It was revealed that statistically significant differences are noted on almost all scales of the questionnaire ("Expression of emotions", "Causes of emotional experiences", "Empathy") and on the overall level of emotional intelligence. The differences are not statistically significant only on the scale "The content of emotions and feelings". Thus, it can be concluded that the divorce of parents has an impact on the level of emotional intelligence in primary school age. Thus, children of divorced parents have a better developed ability to express their emotions, understand the causes of emotional experiences of their own and other people, they have a better developed sense of empathy, as well as their overall level of emotional intelligence is higher than that of children living with both biological parents.

We have suggested that the level of emotional intelligence in primary school age has an impact on the sociometric status of the child. In order to test this hypothesis, an analysis of the results of sociometry in children of divorced parents at primary school age was carried out. The diagnosis was carried out using the "Sociometry" technique (J. Moreno, adapted by Ya. L. Kolominsky). The following results were obtained:

1. "Star" - 16.4\%;

2. "Preferred" - 41.8\%;

3. " Accepted" - 31.3\%;

4. "Isolated" - 10.5\%.

Thus, in this group there is a predominance of children with the sociometric status of "preferred", which in turn is favorable.

To check the connection, the method of analyzing arbitrary conjugacy tables using the chi-square criterion was used. Moreover, the relationship of emotional intelligence with sociometric status was analyzed only by the overall level of development of emotional intelligence, without taking into account data on individual scales.

As a result of statistical analysis, it was revealed that the connection between the level of emotional intelligence and the sociometric status of children of divorced parents in primary school age is not statistically significant (significance level $\mathrm{p}>0.05$ ).

Conclusion. Thus, as a result of the study, it was revealed that children of divorced parents have higher indicators on most scales and on the overall level of emotional intelligence than children living with both biological parents. They better recognize the emotions of other people, adequately express their own, they understand what causes certain emotions in themselves and in people around them, and they experience empathy.

The available works emphasize that the situation of divorce for a child is very stressful, the child is worried about the slightest changes, is afraid of them, especially of conflicts and quarrels between parents, fearing their 
recurrences and the consequences they may incur. F. Dalto in his writings confirms that the divorce symbolizes for a child mourning, reminding a sad experience after the death of one of the parents [12, p. 94]. Perhaps, being afraid of all these consequences and wanting to predict the result of a conflict situation, the child seeks to "read" the emotions of parents, predict further behavior and emotional state. In turn, J. Lofas confirms that divorce is traumatic for the child's personality also because the destruction of the family does not occur as a result of the choice that the child makes and he cannot influence it [13, p. 116]. Most often, children should just accept their parents' decision and choice. Thus, having understood the emotional state of the parent, the reason for his experiences, the child can strive to help the parent. Also, the fact that children of divorced parents in primary school age have a level of emotional intelligence higher than the level of children living with both biological parents may be due to the desire of parents to hide their experiences, not to show them openly, but the child may learn to recognize these emotions more subtly.

According to the results of sociometry, it is noted that the children of divorced parents of primary school age with the sociometric status "preferred" are predominate, which in turn is favorable. Children of divorced parents are accepted in the team, they are in high demand, have a sufficient level of social contacts.

However, the connection between the level of emotional intelligence and sociometric status in this sample of children has not been proven. This indicates the absence of mutual influence of emotional intelligence and sociometric status of children of divorced parents of primary school age.

\section{References}

1. Mestre J. M., Guil R. La regulación de las emociones: una vía a la adaptación personal y social. Madrid : Pirámide, 2012. $189 \mathrm{p}$.

2. Guil R., Gil-Olarte P. Inteligencia emocional y educación: desarrollo de competencias socioemocionales. Manual de inteligencia emocional / M. Mestre, P. Fernández-Berrocal. Madrid : Pirámide, 2007. P. 187-213.

3. Mestre J. M., Guil R., Gil-Olarte P. Inteligencia emocional: algunas respuestas empíricas y su papel en la adaptación escolar en una muestra de alumnos de secundaria. Revista Electrónica de Motivación y Emoción. 2008. № 6 (16). URL : http://reme.uji.es/articulos/avillj302290 6105/texto.html.

4. Mestre J. M., Guil R., Lopes P., Salovey P., Gil-Olarte P. Emotional intelligence and social and academic adaptation to school. Psicothema. 2006. № 18 (Supl. 1). P. 112-117. URL : http://www.psi cothema.com/psicothema. asp?id=3285.

5. Wallon H. L'évolution dialectique de la personnalité [Artículo tomado de Dialectica, 5, 43-49 (1951)]. Enfance. 1963. № 16 (1-2). P. 43-49. URL : https://doi.org/10.3406/enf an.1963.2308.

6. Истратова О. Н. Справочник психолога начальной школы. Ростов-на-Дону : Феникс, 2014. 448 с.

7. Рыжов Д. М. Исследование и анализ развития эмоционального интеллекта у детей младшего школьного возраста. Вестник Сургутского государственного педагогического университета. 2012. № 3. С. 166-171.

8. Комлик Л. Ю., Меренкова В. С. Взаимосвязь эмоционального интеллекта родителей и детско-родительских отношений. Вестник Костромского государственного университета. Серия: Педагогика. Психология. Соииокинетика. 2017. С. 37-40.

9. Соколова А. В. Развитие профессиональной компетентности педагога в сфере взаимодействия с семьей. Вопросы педагогики. 2020. № 9-1. С. 143-148.

10. Горнакова Н. С. К вопросу о развитии эмоционального интеллекта в младшем школьном возрасте. Проблемы теории и практики современной психологи : материалы ХХ Всероссийской научно-практической конференции с международным участием. Иркутск, 2021. С. 90-94.

11. Белопольская А. А. Особенности формирования эмоционального интеллекта младших школьников во внеучебной деятельности (теоретический аспект). Молодой ученый. 2021. № 21 (363). С. 381-383.

12. Зеньковский В. В. Психология детства. Москва : ЭКСМО, 2006. 321 с.

13. Лисина М. И. Развитие общения со сверстниками. Дошкольное воспитание. 1985. № 3. С. 22. 